Vol. 2, No. 1, 2021, pp. 7-12

DOI: https://doi.org/10.2921/08jces71300

Contents lists available at Џournal IICET

Journal of Counseling, Education and Society

ISSN: 2716-4896 (Print) ISSN: 2716-4888 (Electronic)

Journal homepage: https://jurnal.iicet.org/index.php/jces

\title{
Hypnoteaching Learning Theory Analysis in the Learning Process
}

\author{
Fathul Rahma ${ }^{1}$, Neviyarni Neviyarni ${ }^{2}$ \\ ${ }^{12}$ Universitas Negeri Padang
}

\begin{tabular}{|c|c|}
\hline Article Info & ABSTRACT \\
\hline Article history: & \multirow{7}{*}{$\begin{array}{l}\text { Hypnosis is the art of interaction that influences someone by altering their level } \\
\text { of awareness. Not only is hypnosis effective for resolving physical and } \\
\text { psychological difficulties, but it can also be used in an attempt to optimize the } \\
\text { learning process. Hypnosis is known as hypno-teaching in the learning process. } \\
\text { Hypnosis is known as hypnoteaching in the learning process. The secret to the } \\
\text { hypnoteaching technique is how teachers can internally and externally create a } \\
\text { supportive learning atmosphere. They will also believe the learning process is } \\
\text { enjoyable when relaxation is in learning, and when in a relaxed class, it is } \\
\text { guaranteed that students will easily understand the material provided by the } \\
\text { instructor.In essence, teachers are expected to be able to hypnotize students in } \\
\text { this hypnoteaching process, this hypnosis attempts to put students into a calm, } \\
\text { secure and quiet environment so that students can easily embrace any content } \\
\text { and moral messages communicated by the instructor. }\end{array}$} \\
\hline Received Nov $22^{\text {th }}, 2020$ & \\
\hline Revised Dec $16^{\text {th }}, 2020$ & \\
\hline Accepted Jan $17^{\text {th }}, 2021$ & \\
\hline Keyword: & \\
\hline Hypnoteaching & \\
\hline Learning Theory & \\
\hline
\end{tabular}

C 2021 The Authors. Published by IICET.

This is an open access article under the CC BY-NC-SA license

C. ${ }_{\text {BY NC SA }}$ (https://creativecommons.org/licenses/by-nc-sa/4.0

\section{Corresponding Author:}

Fathul Rahma

Universitas Negeri Padang

Email: fathulrahma890@gmail.com

\section{Pendahuluan}

Pembelajaran ialah tumpuan harapan suatu bangsa agar dapat bertahan di tengah pergulatan kehidupan manusia. Penanda keberhasilan suatu proses pembelajaran ditemukan dari mutu Sumber Daya Manusia. Sumber Daya Manusia yang bermutu terlahir dari lembaga pembelajaran yang bermutu. Mutu lembaga pembelajarandipengaruhi oleh kualitas suatu proses pendidikan, karena proses pendidikan bagi hemat penulis ialah ruh dari suatu lembaga pembelajaran. Bagaimanapun"saktinya" suatu kebijakan, ketika kebijakan tersebut tidak sanggup diinterpretasikan secara tepat dan pas dalam proses pendidikan, maka kebijakan tersebut takan mati dan tidak terpakai di dalam sistem pembelajaran saat ini. Contihnya sebut saja kebijakan tentang kurikulum, kenyataan yang terjadi merupakan serangkaian pergantian kurikulum pembelajaran di Indonesia nyatanya sampai saat ini belum memperlihatkan hasil yang signifikan.

Perkembangan suatu negara sangat bergantung pada kualitas dan kuantitas komponennya, yaitu masyarakat, yang merupakan penentu perkembangan ilmu pengetahuan dan teknologi di masa depan. Oleh karena itu keberadaan pendidikan telah diwujudkan sebagai sarana pendidikan yang maju bagi bangsa. Peningkatan kualitas pendidikan melalui pembelajaran tidak terlepas dari upaya peningkatan potensi peserta didik sebagai peserta didik dan komunitas belajar. Saat ini proses pembelajaran di sekolah dilaksanakan dan dikembangkan berdasarkan metode pembelajaran yang mengaktifkan siswa sehingga siswa dapat menemukan keterkaitan antar informasi yang dimilikinya. 
Semua komponen pendidikan harus memandang jauh di depan, memikirkan tentang apa yang akan dihadapi siswa. Salah satu masalah utama Sedang menempuh pendidikan formal (sekolah) Tingkat penyerapan siswa yang rendah dalam menerima pelajaran akan mempengaruhi kinerja siswa. Pada dasarnya, proses pembelajaran itu sampai dewasa Hal ini tetap menempatkan guru pada posisi dominan dan mengurangi kesempatan peserta Siswa berkembang secara mandiri melalui penemuan dan proses pembelajaran.

Dalam proses pendidikan, kegagalan suatu tata cara merupakan kala tata cara tersebut jadi tempat bersandar sangat lama, sehingga menimbulkan seorang tidak dapat mandiri serta bergantung pada tata cara tersebut. Apabila pengajar serta para guru menguasai metode berbicara dengan dasar siuman siswa, pasti hendak menolong dalam proses belajar mengajar. Salah satu tata cara komunikasi yang digunakan serta lumayan terkenal dikala ini merupakan metode hipnosis. Hipnosis ialah seni komunikasi buat pengaruhi seorang dengan mengganti tingkatan kesadarannya.

Hypnoteaching tidak cuma bermanfaat buat menanggulangi kasus yang menyangkut keadaan raga ataupun psikis, melainkan pula bisa digunakan dalam upaya memaksimalkan proses pendidikan. Hipnotis dalam proses pendidikan diketahui dengan sebutan hypno teaching. Menurut Natalia Tri Astutri (2014), hypnoteaching merupakan cara yang kreatif, unik, menarik, dan imajinatif. Hal ini disebabkan oleh guru mengkondisikan siswa untuk siap belajar sebelum proses belajar dimulai dengan memperhatikan aspek emosional dan psikologi siswa. Hal ini dilakukan dengan memberikan sugesti pada siswa menggunakan motivasi, cerita, dan kata-kata positif. Sehingga siswa belajar dengan kondisi fresh. Metode hypnoteaching merupakan metode menarik yang dapat diterapkan Dalam kegiatan pembelajaran, metode ini dianjurkan Secara aktif menjangkau pikiran bawah sadar siswa. Menyarankan Langsung diarahkan ke alam bawah sadar akan berubah lebih efektif Perilaku dibandingkan dengan menargetkan orang yang sadar atau tidak sadar. Sehingga siswa dapat lebih menguasai materi pembelajaran sederhana.

Dengan demikian siswa dapat menguasai materi pembelajaran dengan lebih mudah. Mengapa memilih alam bawah sadar, karena alam bawah sadar memiliki keunggulan lebih besar dalam cara kerja otak. Pikiran bawah sadar adalah gudang dari semua informasi yang dimiliki seseorang. Banyak hal yang tidak bisa diingat oleh pikiran bawah sadar masih bisa diingat dengan jelas oleh pikiran bawah sadar. Masih banyak mata pelajaran yang tidak diingat siswa selama ujian, tetapi mereka bisa Mereka berada dalam kondisi bawah sadar. Hal-hal yang dapat Anda pesan bahan Pelajaran yang mudah diingat adalah berkomunikasi berulang kali Saat siswa berada di sekolah, ciptakan suasana belajar yang mendukung Dalam keadaan santai (kondisi Alpha), kinerja guru sangat atraktif dan menyampaikan Semua emosi atau panca indera terlibat.

\section{Metode}

Tulisan ini mengkaji tentang bagaimana penerapan teori belajar hypnoteaching dalam proses pendidikan. Tata cara penulisan yang digunakan dalam penyusunan tulisan ini merupakan metode deskriptif kualitatif yang termasuk dalam jenis penelitian studi pustaka. Informasi penulis peroleh dengan pencarian, pengklasifikasian, dan penganalisaan sehingga dapat disajikan dalam tulisan ini. Sumber informasi diperoleh lewat riset pustaka dengan pencarian sumber lewat buku-buku yang cocok dan relevan pada bahasan tulisan ini.

\section{Pembahasan}

\section{Pengertian Hypnoteaching}

Menciptakan proses belajar yang lebih menarik, tidak membosankan, dan pasti mencapai tujuan dengan efektif Kemudian menentukan pembelajaran dari masing-masing institusi pendidikan Sadarilah harapan dengan banyak cara. yang itu Di bidang pendidikan sudah mulai berkembang Hipnose. Hipnosis adalah teknik, metode atau metode Belajar menggunakan bahasa saat menyampaikan materi Pikiran bawah sadar dapat memiliki daya tarik tersendiri bagi siswa.

Di Indonesia, hypnoteaching lebih sering disebut dengan dua nama, yaitu hypnostudying dan hypnolearning. Namun mengacu pada arti yang sama (Hana, 2014). Hypnoteaching merupakan aktivitas menghipnotis atau menyugesti siswa agar menjadi pintar dan melejitkan semua anak menjadi bintang (Jaya, 2010: 4). Dengan hypnoteaching siswa diberi sugesti agar prestasi belajarnya meningkat. Hal ini diupayakan dengan mempengaruhi siswa dengan kalimat-kalimat positif dan membuat suasana belajar yang menyenangkan. Istilah hypnoteaching berasal dari kata hypnosis dan teaching. Hipnosis berasal dari kata hypnos yang berarti tidur. Namun, hipnosis itu sendiri bukan tidur. Secara sederhana, hipnosis adalah fenomena yang mirip tidur, alam bawah sadar lebih mengambil peranan dan alam sadar berkurang (Noer, 
2010: 17). Dalam kondisi hipnos, fungsi pikiran sadar yang bersifat cerdas, kritis, logis,dan analitis tidak 24 difungsikan. Sementara itu, pikiran bawah sadar yang lugu, polos, jujur, dan terkesan bodoh ketika berfungsi.

Menurut Navis (2013), hypnoteaching merupakan suatu situasi pembelajaran dengan memanfaatkan sugesti-sugesti positif untuk memudahkan dalam memotivasi peserta didik. Sedangkan menurut Hakim dalam Turasih (2014), menyatakan bahwa hypnoteaching (hypno dalam proses pembelajaran) adalah kondisi ketika peserta didik mudah menerima saran, informasi, dan sugesti tertentu.

Hypnoteaching merupakan perpaduan pengajaran yang melibatkan pikiran sadar dan bawah sadar. Metode pembelajaran ini adalah pembelajaranyang kreatif, unik, sekaligus imajinatif (Haves, 2013). Menurut Putu (2014), hypnoteaching merupakan pembelajaran yang dalam menyampaikan materi, guru memakai bahasa-bahasa bawah sadar yang bisa menumbuhkan ketertarikan tersendiri kepada siswa. Dari asal katanya, hypnoteaching merupakan perpaduan dari dua kata, yaitu hypnosis dan teaching.

Hipnosis berarti mensugesti dan teaching yang berarti mengajar. Jadidapat dikatakan bahwa Hypnoteaching adalah usaha untuk menghipnosisatau mensugesti siswa supaya menjadi lebih baik dan prestasinya meningkat (Putu, 2014). Metode hypnoteaching dilakukan dengan menggunakan hal-hal yangmenarik, seperti permainan, yelling, pujian, dan lain-lain. Penggunaan permainan hendaknya tidak berlebihan, karena bias berakibat tidak baik dan dapat menghancurkan efektivitas belajar (Hamruni, 2014).

Hypnosis merupakan fenomena mirip tidur, tetapi bukan tidur, hypnoteaching dalam ulasan di mari bisa dimaksud bagaikan proses pengajaran yang bisa membagikan sugesti kepada para peserta didik. Ada pula arti tidur di mari bukan berarti keadaan tidur secara wajar di malam hari, tetapi menidurkan sejenak kegiatan benak siuman serta mengaktifkan pikiran bawah sadar(Noer. 2010: 117).Bagi Bobby DePotter serta Mike Hernacki dalam harian riset yang ditulis oleh Ratnawati melaporkan kalau eksperimen yang dicoba oleh Dokter George Lozanov yang berkutat pada" suggestology" ataupun" suggestopedia" menciptakan suatu prinsip kalau sugesti bisa serta tentu pengaruhi suasana serta hasil belajar. Serta, tiap perinci apapun bisa membagikan sugesti positif ataupun negatif (Ratnawati, 2005: 61). "Tata cara hypnoteaching pula bisa didefinisikan bagaikan tata cara pendidikan yang dalam mengantarkan modul, guru mengenakan bahasabahasa dasar siuman yang dapat meningkatkan ketertarikan tertentu kepada peserta didik" (Yustisia, 2012: 75).

Hypnoteaching menekankan komunikasi bawah sadar antara siswa di dalam dan di luar kelas. Ini dapat dilakukan dengan berbagai cara, seperti sugesti dan imajinasi. Rekomendasi memiliki kekuatan luar biasa. Kemampuan untuk terus bersuara di otak dapat membuat seseorang memikirkan ide-idenya. Imajinasi adalah proses membayangkan pertama dan kemudian melanjutkan. Dalam hal ini, guru harus bisa membiarkan siswa berekspresi dan berimajinasi (Hasbullah, 2015).

Kunci dari hypnoteaching sesungguhnya merupakan bagaimana guru dapat menghasilkan lingkungan belajar yang aman secara intern (psikis) ataupun ekstern (raga/fisilk). Sebab ketika kenyamanan telah terdapat dalam pendidikan, maka peserta didik akan merasakan pula proses belajar yang mengasyikkan, serta ketika dalam suatu pendidikan rasa aman ditentukan modul yang di informasikan guru hendak gampang sekali diserap oleh peserta $\operatorname{didik}($ Ratnawati, 2005: 71). Hal itu dapat terjalin sebab keadaan aman merupakan keadaan yang diciptakan oleh guru) dengan suatu komunikasi yang bermanfaat bawa subjek hipnotis(peserta didik) kealam bawah sadarnya(Gunawan, 2007: 54).

Bila guru dalam keadaan psikis yang tidak baik yang disebabkan karena tidak dapat mengendalikan jiwa hati serta pikirannya, sehingga guru akan mudah tersinggung dan marah kepada peserta didik yang menjadi pelampiasannya, perilaku guru yang semacam itu menampilkan seseorang guru yang tidak berkompeten dan hal itu tidak selaykanya ada dalam kepribadian seorang guru.( Noer, 2010: 131). Belajar merupakan sebuah perilaku, siswa pun perlu mendapat input atau sugesti yang baru untuk mengubah makna belajar di dalam otak siswa. Dengan demikian, belajar menjadi sesuatu yang menyenangkan, mengasyikkan, dan menjadi proses berkesinambungan yang dibutuhkan. Pikiran sadar atau otak kiri di dalam kepala manusia hanya berperan $12 \%$, sedangkan pikiran bawah sadar atau otak kanan berperan $88 \%$. Hal itu berarti dengan memaksimalkan potensi pikiran bawah sadar, maka di dalam diri seseorang akan terjadi peningkatan kecerdasan yang luar biasa (Jaya, 2010: 11).

Metode hypnoteaching merupakan metode menarik yang dapat diterapkan Dalam kegiatan pembelajaran, metode ini dianjurkan Secara aktif menjangkau pikiran bawah sadar siswa. Menyarankan Langsung diarahkan ke alam bawah sadar akan berubah lebih efektif Perilaku dibandingkan dengan menargetkan orang yang sadar atau tidak sadar. Sehingga siswa dapat lebih menguasai materi pembelajaran sederhana.

Dengan demikian siswa dapat menguasai materi pembelajaran dengan lebih mudah. Karena alam bawah sadar memiliki keunggulan lebih besar dalam cara kerja otak. Pikiran bawah sadar adalah gudang dari semua 
informasi yang dimiliki seseorang. Banyak hal yang tidak bisa diingat oleh pikiran bawah sadar masih bisa diingat dengan jelas oleh pikiran bawah sadar. Masih banyak mata pelajaran yang tidak diingat siswa selama ujian, tetapi mereka bisa Mereka berada dalam kondisi bawah sadar. Hal-hal yang dapat Anda pesan bahan Pelajaran yang mudah diingat adalah berkomunikasi berulang kali Saat siswa berada di sekolah, ciptakan suasana belajar yang mendukung Dalam keadaan santai (kondisi Alpha), kinerja guru sangat atraktif dan menyampaikan Semua emosi atau panca indera terlibat.

Langkah-langkah dalam metode hypnoteaching bertujuan untuk mendidik para guru supaya jadi guru yang handal, menjiwai kedudukannya bagaikan seseorang guru yang ialah wujud yang digugu serta ditiru yang kesimpulannya sanggup membagikan contoh yang baik dari segi berdialog, bertingkah laku, ataupun berpenampilan, sebab peserta didik tidak hendak dapat jadi semacam apa yang kita mau jika guru bagaikan si pemberi perintah malah malah menampilkan penampilan, ataupun perbuatan yang sangat bertolak balik dari apa yang di perintahkan kepada peserta didik.

\section{Manfaat Hypnoteaching}

Permasalahan yang muncul pada peserta didik timbul akibat terdapat kebutuhan psikis yang belum terpenuhi. Serta peserta didik didik tidak dapat menyampaika, memberitahu ataupun tidak tau bagaiaman cara memberitahu kepada guru, apalagi takut akan dimarahi oleh orang tuanya. Yang terlihat di kenyataan merupakan perubahan sikap anak yang lama-lama terus menjadi menyimpang(Gunawan, 2007: 4). Berkenaan dengan kebutuhan anak bagi Gunawan (2007:9) sesungguhnya apa yang diperlukan anak jawabannya hendak sama dengan apa yang diperlukan manusia, serta yang diperlukan manusia merupakan rasa nyaman. Kebutuhan ini menempati posisi sangat besar dibanding kebutuhan yang lain semacam perasaan dicintai, dihargai, ataupun diterima.

Ketika peserta didik mengalami kesulitan justru guru yang malah menjatuhkan peserta didik yang hadapi kegagalan dalam proses belajar mengajar di kelas. Sementara itu sesungguhnya dalam keadaan di mana seseorang peserta didik yang tengah hadapi kesusahan serta kegagalan merupakan keadaan di mana seseorang peserta didik memerlukan motivasi supaya senantiasa ingin berupaya sampai sukses (Meggit, 2013: 24). Lebih dari itu, penerapan hypnoteaching diperkirakan akan sangat berarti dalam upaya pendidikan, yang paling utama untuk peserta yang menghadapi kegoncangan jiwa serta kesusahan dalam memahami suatu pelajaran, perihal itu dapat dilihat dari khasiat tata cara hypnoteaching sebagai berikut: 1) Pendidikan jadi mengasyikkan serta lebih menyenangkan baik untuk peserta didik ataupun untuk guru. 2) Pendidikan bisa menarik atensi peserta didik lewat bermacam kreasi game yang diterapkan oleh guru. 3) Guru jadi lebih sanggup dalam mengelola emosinya.4) Pendidikan bisa meningkatkan ikatan yang harmonis antara guru serta peserta didik. 5) Guru bisa menanggulangi peserta didik yang memiliki kesusahan belajar lewat pendekatan personal. 6) Guru bisa meningkatkan semangat peserta didik dalam belajar lewat game hypnoteaching(Yustisia, 2012: 80).

Mengingat bahwa sekolah merupakan salah satu tempat buat mencapai pembelajaran, tempat mencerdaskan otak peserta didik serta tempat penanaman nilai- nilai kebangsaan, hendak namun pada realitasnya peserta didik yang sesungguhnya memerlukan tutorial buat dapat sembuh dari kegoncangan jiwa yang membuat peserta didik jadi bandel. Kala sikap peserta didik menampilkan sikap yang tidak cocokyang diharapkan, secara tidak langsung itumenampilkan suatu sinyal untuk pihak sekolah serta orangtua buat menolongnya, bukan buat dimarahi, dipermalukan apalagi disingkirkan.

\section{Aplikasi Metode Hypnoteaching dalam Pembelajaran}

Hypnoteaching bukanlah hal baru dalam dunia pendidikan telah mengalami tampilan baru dalam strategi pembelajaran. Pada prinsipnya hypnoteaching adalah proses penurunan gelombang otak menjadi lebih mudah untuk menghadapi proses pembelajaran kapan saja. Dalam hal ini, guru memegang peranan penting dalam keberhasilan implementasi hypnoteaching (Muhammad Zuhri, \& Sukamianti, 2015).

Dengan motivasi yang diberikan secara tidak langsung seorang guru tengah berupaya bawa didik dalam keadaan yang nyaman sangat relaks serta aman, kala telah merasa relaks serta aman,barulah guru diharapkandapat mengucapkan kesekian kali sugesti- sugestipositif tentang muriddan mengantarkan modul dengan metode- metode lain yang menunjang memahamkan peserta didik tentang modul.

Dalam mempraktikkan tata cara hypnoteaching diharapkan guru dapat jadi magnet untuk peserta didik, maksudnya bilaguru menginginkan ketenangan kelas dalam pendidikan, hingga guru sendiri wajib berlagak tenang dahulu, bila guru menginginkan pesertadidiknya gemar membaca, hingga guru wajib gemar membaca, bila guru menginginkan peserta didiknya giat belajar, hingga guru wajib giat belajar.Jadi hukum tarik 
menarikmerupakan perihalyang dimaksudkan dalamtata cara hypnoteaching, bila guru menginginkan jadi apa yang di idamkan, hingga guru wajib dapat jadiapa yang gurumau dari peserta didik (Noer, 2010: 127).

Berkenaan dengan itu, bila ditelaah lebih dalam lagi kronologinya, di atas dipaparkan kalau carakerja alam bawah sadar otak dasar sifatnya sangat polos menerima apapun data yang baik ataupun tidak, jadi apapun yang guru ucapkan serta yang guru perlihatkan ialah wujud sugesti yang akan diterima oleh alam bawah sadar peserta didik yang akan mempengaruhi keberhasilan peserta didik dalam belajar, serta jangan hingga membuat suatu yang membingungkan otak, ketika yang diperlihatkan oleh guru tidak cocok dengan apa yang diajarkan oleh guru, hal itu akan mengganggu tercapainya suatu tujuan. Misalnya, guru menyuruh peserta didik supaya tiap kuku yang telah panjang segera dipotong, sebabkuku panjang sangatmengusik kesehatan,namun pada realitasnya apa yang diperlihatkan guru sangat tidak cocok dengan apa yang diperintahkan guru, namun nyatanya guru tersebut kukunya panjang serta tidak dipotong.

Bagi Muhammad Noer dalam bukunya N. Yustisia, terdapat sebagian langkah yang butuh dicoba oleh guru dalam pengaplikasian metode hypnoteaching ini adalah : Pertama, kesuksesan seseorang sangat bergantung pada niatnya buat tetap berupaya serta bekerja dalam menggapai kesuksesan yang mau diraih. Hasrat yang besar serta tekad yang kokoh hendak meningkatkan motivasi serta komitmen yang besar pada bidang yang ditekuni. Sebagaimana seseorang guru, guru yang memiliki motivasi serta komitmen yang kokoh terhadap profesinya, tentu akan senantiasa berupaya melakukan yang dan memikirkan serta memantaskan diri menjadi guru yang teladan bagi peserta didiknya.

Kedua, guru harus membiasakan diri dengan peserta didiknya. Prinsip dalam langkah ini merupakan manusia cenderung ataupunlebih suka berkumpul, berhubungandengan manusia yang memiliki banyak kesamaan dengannya. Dengan demikian secara alamiah serta naluriah, setiap orang tentu ingin merasa aman serta bahagia berkumpul dengan orang lain yang memiliki kesamaan dengannya. Karena ini hendak membuat seorang merasa aman kala terletak di dalamnya, lewat rasa aman yang bersumber dari kesamaan gelombang otak tersebut, tiap pesan yang di informasikan dari satu orang pada orang lain hendak dapat diterima serta dimengerti dengan baik.

Ketiga, menggunakan kata positif ini cocok dengan metode kerja alam bawah sadar yang menerima apa saja yang diucapkan oleh siapa saja baik negatif ataupun positif,sehingga sebaiknya guru menyesuaikan penggunaan kalimat positif agar tidak terdapat perihal negatif yang diterima oleh bawah sadar peserta didik

Keempat, menggunakan pujian. Salah satu perihal yang berarti yang wajib diingat guru merupakan terdapatnya reward serta punishment. Pujian merupakan reward kenaikan harga diri seorang. Pujian ini ialah salah satu metode buat membentuk konsep diri seorang. Sedangkan punishment ialah hukuman ataupun peringatan yang diberikan gurukala peserta didik melaksanakan aksi yang kurang baik, pastinya dalam membagikan punishment guru melaksanakannya dengan hati- hati supayapunishment tersebut tidak membuatpesertadidik merasa rendah diriserta tidak bergairah.

Kelima yaitu proses pemberian teladan ataupun contoh lewat perkataan serta sikap yang tidak berubahubah. Perihal ini ialah suatu yang sangat berarti serta jadi kunci sukses tidaknya dalam menunjang dan mengoptimalkan suatu pendidikan dengan tata cara hypnoteaching, hendaknya guru pula memahami modul pendidikan secara komprehensif. Perihal ini bisa dicoba dengan mengaitkan peserta didik secara aktif dalam proses pendidikan, sebisa bisa jadi mengantarkan modul secara kontekstual, berikan peluang peserta didik melaksanakan pendidikan secara kolaboratif, berikan umpan balik secara langsung kepada peserta didik. Tidak kalah berarti pemberian motivasi serta sugesti positif wajib selalu dicoba sepanjang pendidikan berlangsung(Yustisia, 2012: 85- 88).

Guru memiliki peran yang yang besar dalam penerapan tata cara hypnoteaching. Hingga dari itu, buat dapat meminimalisir kekurangan tersebut, guru wajib banyak belajar serta berlatih guna mengoptimalkan pemakaian tata cara hypnoteaching. Serta untuk guru yang masih asing dengan tata cara hypnoteaching ini, diharapkan buat dapat menerapkannya dengan menyadari tanggungjawabnya, guru ditentukan hendak sanggup menerapakannya. Perihal itu disebabkan tata cara hypnoteaching ialah tata cara yang di dalamnya menekankan faktor psikologi. Guru dituntut memiliki jiwa yang normal yang wajib ditunjukkan dengan bahasa lisan yang penuh motivasi serta bahaa yang penuh semangat, dan penampilan yang memiliki kenyamanan tertentu bila ditatap oleh peserta didik. Buat dapat jadi figur yang mempengaruhi, tidak lepas dari kekuatan dari dalam diri. alangkah baiknya kerutinan dzikrullah dapat kerap dicoba oleh siapa saja spesialnya guru, sebab perihal itu hendak jadi suatu amal baik untuk diri sendiri, dan hendak memiliki khasiat oleh orang lain, dalam hal ini akan sangat menolong guru menguatkan pribadinya menjadi guru yang memiliki kepribadian yang baik. 
Menurut Iman seorang pakar Hypnoteraphy dari Indonesia Board of Hypnoteraphy (IBH), adapun komponen-komponen yang harus ada dalam metode hypnoteaching yaitu: 1. Hello Effect (Sapaan di awal). 2. Sell Talk (Menyampaikan kata-kata positif, memberikan pujian). 3. Paccing (Menyamankan posisi dengan peserta didik) 4. Leading (Memberikan perintah atau intruksi kepada siswa). 5. Relaxation (Membuat siswa menjadi rilex dan nyaman). 6. Anchoring (Jangkar emosi yang dapat digunakan sebagai penguhubung dalam mengingat pada suatu pengalaman tertentu) (Ega Rima Wati, 2016).

\section{Kesimpulan}

Berdasarkan uraian diatas dapat disimpulkan bahwa hypnoteaching secara tidak langsung sudah dipraktekkan oleh sebagian guru. Konsep hypnoteaching sesungguhnya ialah metode guru berpersepsi dalam mengatur pikirannya dan pikiran peserta didiknya dalam proses pendidikan dan pembelajaran dalam kelas. Hypnoteaching tidaklah perihal yang asing, sebab itu dalam prakteknya jangan merasa khawatir tidak bisa melakukannya sebelum mencoba secara utuh dalam melaksanakan metode ini. Sebab pikiranlah yang membentuk realitas dan kenyataan dalam proses pembelajaran itu. Agar bisa mempraktikkan hypnoteaching dalam pendidikan, seseorang pendidik sebaiknya mempunyai keyakinan yang kokoh dan kuat kalau ia sanggup dalam mentransfer pengetahuan kepada seluruh peserta didiknya. Pendidik wajib mempunyai keahlian kemampuan komunikasi yang baik, dan menguasai berbagai bermacam tata cara serta metode pengajaran, sehingga bisa menghasilkan style dan gaya mengajarterbaiknya. Serta yang terakhir para pendidik mempersiapkan bahan serta perlengkapan pendukung pengajaran dan sanggup memakai.

\section{Referensi}

Ade W. Gunawan. (2007). Hypnosis: The Art of Subconscious Communication, Meraih Sukses dengan Kekuatan Pikiran. Jakarta: Gramedia Utama

Ali Akbar Navis. (2013). Hypnoteaching Revolusi Gaya Mengajar untuk Melejitkan PrestasiSiswa, Yogjakarta: Arruzz Media

Dj, Muhammad Zuhri \& Sukarnianti. (2015). Using Hypnoteaching Strategy to Improve Students Writing Ability. STAIN Watampone : Dinamika Ilmu. Vol 15.

Hamruni. (2014). Pembelajaran Berbasis Edutainment: Landasan Teori dan Metode-Metode Pembelajaran AktifMenyenangkan (PAIKEM), (Yogyakarta: Investidaya

Hana Pertiwi. (2014). Hynoteaching untuk Paud dan TK. Diva Press. Jogjakarta

Hasbullah. (2015). Pengaruh Penerapan Metode Hypnoteaching Terhadap Motivasi Belajar Mahasiswa Universitas Indraprasta PGRI". Jurnal Formatif

Haves Derindo. (2013). Penerapan Strategi Pembelajaran Resiprokal Disertai dengan Metode Hypnoteaching pada Pembelajaran Matematika Siswa Kelas VII SMPN Padang". Jurnal Pendidikan

Jaya Novian Triwidia. (2010). Hypnoteaching "Bukan Sekedar Mengajar. Jakarta : D-Brain.

Meggit, Carolyn. (2013). Memahami Perkembangan Anak. Indeks: Jakarta

Natalia Tri Astuti. (2014). "Studi Eksperimental Model Pembelajaran Hypnoteaching Terhadap Hasil Belajar Kosakata Belajar Bahasa Inggris Peserta Didik, Jurnal Ilmiah Kependidikan. Vol.1.No.1 (Maret 2014)

Noer, Muhammad. (2010). Hypnoteaching for Success Learning. PT. Bintang Pustaka Abadi: Yogyakarta

Putu Diantari. (2014). Pengaruh Model Pembelajaran Problem Based Learning Berbasis Hypnoteaching Terhadap Hasil Belajar Matematika Siswa Kelas V SD". Jurnal Mimbar PGSD Universitas Pendidikan Ganesha

Ratnawati. (2005). Aplikasi Quantum Learning, Jurnal Pendidikan Islam”. (Vol. XIV, No. 1, Mei/2005)

Turasih.(2014). Penggunanan Metode Hypnoteaching Untuk Meningkatkan PembelajaanMatematika Tentang Pecahan pada Siswa Kelas V SDN 1 Banjarejo Tahun Ajaran 2013-2014. Jurnal Pendidikan. h. 2

Yustisia.N. (2012). Hypnoteaching seni mengeksplorasi otak peserta didik. Ar-ruzz Media: Jogjakarta 